\title{
PENGEMBANGAN INSTRUMEN TES DIAGNOSIS KONSEP IPA FISIKA
}

\author{
Defrina Natalia, Jeffry Handhika, Farida Huriawati \\ Program Studi Pendidikan Fisika,Universitas PGRI Madiun, Indonesia
}

\begin{abstract}
The objectives of this research are: (1) to know how to develop instrument of diagnosis test of science physics concept in junior high on material of vibration of wave, sound, and light and optics; (2) To know the feasibility of diagnostic test instrument of IPA Physics concept in junior high school based on validator on material of vibration of wave, sound, and light and optics. The development model used is the 4-D. The design of product development trial in this research is expert validation, small class test. The trial subjects were 7 students for the first stage of the class test of class VIII B, and 9 students for the second phase of class test of class VIII B SMPN 14 Madiun. The results showed that: 1) The steps of making the Diagnostic Test Instrument in this research are front end analysis, student analysis, goal specification, making test instrument with Cl-C4 indicator, determining the format, design, expert validation, and class test done two steps; 2) Quality of the Test Instrument This diagnosis obtains a good category in which the material has been assessed to obtain a percentage of 95.33\% (very feasible); 3) The result of validity test 34 about the essays of class test VIII B SMPN 14 Madiun stage 1 is valid as many as 25 items with very reliable category; the results of validity test 25 double choice test class VIII B SMPN 14 Madiun phase 2 valid as many as 15 items with very reliable category.
\end{abstract}

Keywords: Diagnostic Test Instruments, 4-D, Validity Test, Reliability Test.

\begin{abstract}
Abstrak
Penelitian ini bertujuan: (1) Mengetahui cara mengembangkan instrumen tes diagnosis konsep IPA Fisika di SMP pada materi Getaran Gelombang, Bunyi, serta Cahaya dan Optik; (2) Mengetahui kelayakan instrumen tes diagnosis konsep IPA Fisika di SMP berdasarkan validator pada materi Getaran Gelombang, Bunyi, serta Cahaya dan Optik. Model pengembangan yang digunakan adalah adaptasi model pengembangan prosedural 4-D. Desain uji coba produk pengembangan dalam penelitian ini yaitu validasi ahli, uji kelas kecil. Subjek uji coba adalah 7 siswa untuk tahap I uji kelas kecil dari kelas VIII B, dan 9 siswa untuk tahap II uji kelas kecil kelas VIII B SMPN 14 Madiun. Hasil penelitian menunjukkan bahwa: 1) Langkah-langkah pembuatan Instrumen Tes Diagnosis dalam penelitian ini yaitu analisis ujung depan, analisis siswa, spesifikasi tujuan, membuat instrumen tes dengan indikator $\mathrm{C} 1-\mathrm{C} 4$, menentukan format, perancangan, validasi ahli, dan uji kelas yang dilakukan dua tahap; 2) Kualitas Instrumen Tes Diagnosis ini memperoleh kategori baik dimana yang telah dinilai oleh ahli materi memperoleh presentase sebesar 95,33\% (sangat layak); 3) Hasil uji validitas 34 soal essay uji kelas VIII B SMPN 14 Madiun tahap 1 dinyatakan valid sebanyak 25 butir soal dengan kategori sangat reliabel; hasil uji validitas 25 soal pilihan ganda uji kelas VIII B SMPN 14 Madiun tahap 2 dinyatakan valid sebanyak 15 butir soal dengan kategori sangat reliabel
\end{abstract}

Kata Kunci: Instrumen Tes Diagnosis,4-D, Uji Validitas, Uji Reliabilitas

DOI :http://dx.doi.org/10.21067/mpej.v1i2.

Diterima: Februari 2017; Disetujui: Maret 2017

\footnotetext{
* Corresponding Author:

defrinanatalia134@gmail.com
} 


\section{PENDAHULUAN}

Kegiatan belajar merupakan hal dasar yang harus dilakukan terutama bagi seorang pelajar atau siswa. Belajar akan menjadi sesuatu yang bermakna bila menjadikannya sebagai kebiasaan yang perlu dilakukan setiap hari. Dalam (I Gusti Ayu Tri Agustina 2013: 276), menurut pandangan konstruktivis, dalam proses pembelajaran IPA disediakan serangkaian pengetahuan berupa kegiatan nyata yang rasional atau dapat dimengerti siswa sehingga siswa dapat memahami konsep dan memecahkan permasalahan di dalam soal. Rata-rata skor prestasi sains siswa Indonesia pada TIMSS 2007 adalah 433, dengan skor tersebut siswa Indonesia menempati peringkat 35 dari 49 negara. Penelitian oleh Vidya Matarani Salma, dalam Unnes Physics Education Journal tahun 2016, di Universitas Negeri Semarang, dengan judul "Pengembangan E-Diagnostic Test Untuk Mengidentifikasi Pemahaman Konsep Fisika Siswa SMA Pada Pokok Bahasan Fluida Statis", penilaian kelayakan e-diagnostic test dilakukan oleh pakar evaluasi dan pakar media, yakni dosen, guru Fisika, dan guru komputer. Selain itu, penilaian kelayakan e-diagnostic test juga ditinjau dari respon siswa terhadap implementasi produk. Uji kelayakan instrumen e-diagnostic test didasarkan pada Lampiran Peraturan Menteri Pendidikan Nasional No. 20 Tahun 2007. Uji kelayakan media ediagnostic test didasarkan pada pedoman penilaian kelayakan oleh Badan Nasional Pendidikan (BSNP) yang telah dimodifikasi. Uji keefektifan e-diagnostic test dilakukan dengan mengkorelasikan nilai ulangan harian siswa dengan nilai siswa yang diperoleh pada e-diagnostic test. Kelemahan penelitian produk yang dikembangkan ini hanya menyediakan menu untuk siswa dan admin. Selain itu, sistem penyimpanan jawaban siswa belum bisa mengantisipasi kondisi khusus, seperti listrik mati. Berdasarkan hasil wawancara dengan guru mata pelajaran IPA di SMPN 14 Madiun, siswa kelas VIII memiliki nilai rata-rata yang tergolong dibawah KKM yang ditetapkan di sekolah yaitu 60, dan instrumen yang digunakan oleh guru untuk mengukur tingkat pemahaman siswa pada mata pelajaran IPA adalah melakukan latihan soal dan ulangan harian.

Perlunya melakukan tindakan penyelidikan untuk mengetahui kesulitan belajar siswa adalah dengan melakukan observasi, interview, tes diagnostik atau menggunakan dokumen catatan harian. Informasi mengenai kesulitan belajar 
siswa dapat dikumpulkan melalui tes yang dirancang untuk keperluan diagnosis.Dari uraian di atas, untuk mengukur pemahaman konsep IPA Fisika, maka tes diagnosis perlu dilakukan agar mengetahui tingkat penguasaan siswa terhadap materi pelajaran yang telah diberikan guru. Pengembangan tes diagnostik ini sengaja dirancang untuk mengetahui kekuatan dan kelemahan pemahaman konsep pada siswa.

Tujuan dari penelitian ini adalah untuk mengetahui cara mengembangkan instrumen tes diagnosis konsep IPA Fisika di SMP pada materi Getaran Gelombang, Bunyi, serta Cahaya dan Optik, dan untuk mengetahui kelayakan instrumen tes diagnosis konsep IPA Fisika di SMP berdasarkan validator pada materi Getaran Gelombang, Bunyi, serta Cahaya dan Optik.

\section{METODE PENELITIAN}

Prosedur pengembangan yang digunakan adalah adaptasi dari model pengembangan 4-D (FourD) yang dikembangkan oleh $\mathrm{S}$, Thagarajan Dorothy S. Sammel dan Melvyn I. Semmel. Pada model ini terdiri dari empat tahap pengembangan. Diantaranya adalah define, design, develope, dan desseminate. Subyek yang digunakan dalam penelitian ini adalah siswa kelas VIII B, SMPN
14Madiun.Pengumpulan data menggunakan soal tes. Instrumen yang digunakan pada penelitian ini adalah lembar validitas materi dan soal. Lembar penilaian validasi ahli dirancang untuk mendapatkan penilaian dan masukan/saran dari validator. Instrumen diujikan pada kelas kecil SMPN 14 Madiun. Hasil analisis instrumen menggunakan uji validitas, reliabilitas, taraf kesukaran, dan daya beda.

\section{HASIL DAN PEMBAHASAN \\ Tahap Pendefinisian (Define)}

Langkah pertama yang dilakukan pada tahap ini adalah dilakukannya wawancara kepada guru dan siswa. Hasil yang diperoleh pada tahap ini sebagian besar siswa mengaku pelajaran fisika sebagai pelajaran yang sulit. Di samping itu guru kurang mengerti penggunaan instrumen evaluasi yang baik. Subyek penelitian adalah siswa kelas VIII SMP/MTs. Materi instrumen tes diagnosis pada kelas VIII yaitu materi getaran dan gelombang, bunyi, serta cahaya dan optik. Materi tersebut juga didominasi materi yang sering ditemui dalam kehidupan sehari-hari. Hasil wawancara dan observasi selanjutnya dibuat desain awal instrumen tes diaggnosis yang mengandalkan pengetahuan dan pemahaman siswa. 


\section{Tahap Perancangan (Design)}

Peneliti mengembangkan instrumen tes diagnosis konsep IPA Fisika tingkat SMP/Mts. Mengacu pada hal tersebut, peneliti berfokus pada materi pelajaran Fisika kelas VIII SMP/MTs semeter genap, penelitian ini dilakukan melalui dua tahap. Tahap 1 meliputi materi getaran dan gelombang, bunyi, serta cahaya dan optik. Soal berjumlah 34 buah dalam bentuk essay singkat. Tahap 2 soal berbentuk pilihan ganda dengan jumlah 25 soal yang telah divalidasi oleh para ahli. Perangkat instrumen tes yang digunakan adalah instrumen tes multiple choice yang didapatkan dari soal essay yang telah di telah divalidasi ahli dan sudah diujikan pada kelas VIII B dengan jumlah 7 siswa, tahap eksplorasi dengan 1 alternatif jawaban (stem) dan 3 alternatif jawaban salah atau pengecoh (distractor). Hal pertama adalah menentukan indikatorindikator soal dan mencocokkan indikator dan menentukan kisi-kisi soal. Indikator soal kemampuan berpikir tingkat tinggi yang digunakan adalah berpikir kritis, kreatif, dan pemecah masalah.

Desain tampilan instrumen tes ukuran $21 \mathrm{~cm} \mathrm{x} 29 \mathrm{~cm}$ (A4). Gambar yang berkaitan dengan instrumen tes diambil dari contoh bahasan yang ada dikehidupan sehari-hari. Pembuatan gambar dilakukan dengan manual yang kemudian gambar tersebut di scan dan dimasukkan dalam instrumen tes. Sebagian gambar juga diambil dari sumber internet dengan menyertakan alamatnya pada soal. Desain instrumen tes diagnosis konsep IPA Fisika adalah sebagai berikut :

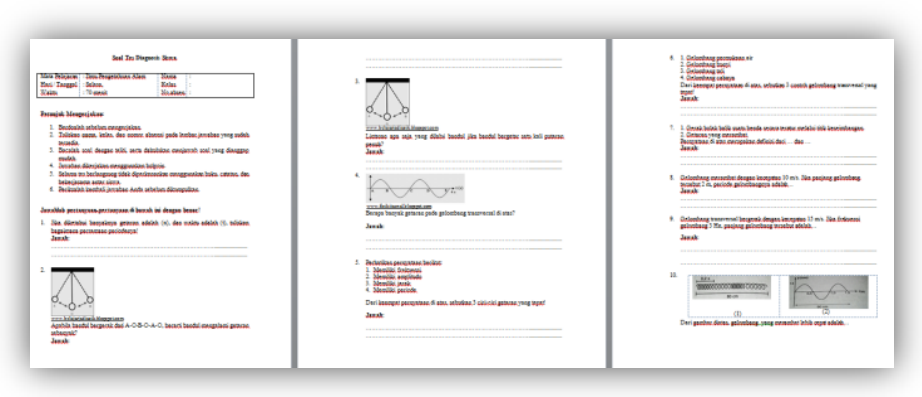

\section{Gambar 1 Design soal tes diagnosis essay}

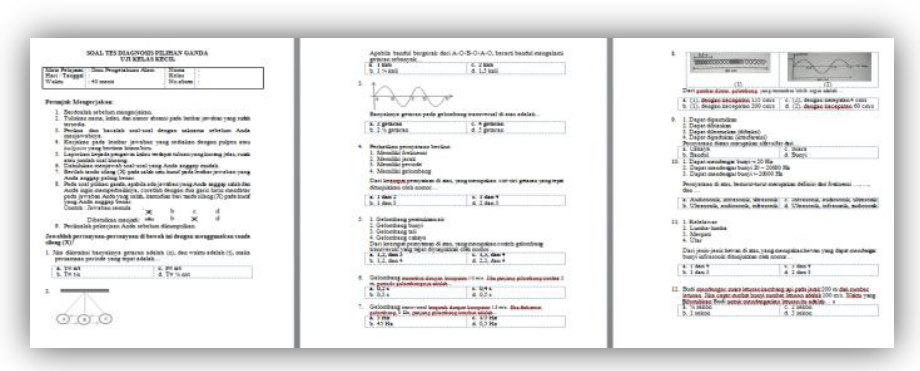

Gambar 2. Design soal tes diagnosis pilihan ganda

\section{Tahap Pengembangan (Develope)}

Validasi ahli sebagai uji perseorangan meliputi validator materi sebanyak dua orang guru IPA Fisika tingkat SMP/Mts. Instrumen tes mendapatkan kriteria penilaian sangat layak dengan nilai $95,33 \%$ melalui 
validator materi. Dengan beberapa kriteria yang akan memberikan dampak bagi siswa dan guru. Hal ini menunjukkan bahwa materi dalam instrumen tes mata pelajaran fisika yang dikembangkan telah sesuai. Selanjutnya dijadikan sebagai bahan perbaikan untuk memperbaiki produk, sehingga produk layak digunakan pada kelas uji coba. Uji coba kelas kecil terdapat dua tahap yaitu uji coba kelas kecil 34 soal essay dan uji coba kelas kecil 25 soal pilihan ganda.

Instrumen tes 34 soal dalam bentuk essay yang yang meliputi indikator C1-C4. Setelah soal essay divalidasi oleh para ahli dan sudah dikatakan layak untuk digunakan tanpa revisi selanjutnya produk dapat diujikan pada kelas kecil. Untuk pengujian kelas kecil dipilih kelas VIII B SMPN 14 Madiun yang berjumlah 7 siswa. Setelah dilakukan tes, hasil dari pekerjaan siswa diuji secara kevalidan, reliabilitas, daya beda, dan taraf kesukaran. Hasil uji validitas dan reliabilitas yang didapatkan dari analisis butir soal didapatkan 25 soal yang valid,dari 25 soal tersebut memenuhi nilai validitas lebih besar dari $\mathrm{r}$ tabel yaitu 0,754. Nilai dari reliabilitas sebesar 0,957 dengan kriteria reliabel tinggi. Setelah hasil perhitungan taraf kesukaran soal tes diagnosis essay kelas kecil dikategorikan mudah sebanyak 13 soal, yaitu nomor (5,
$6,8,9,11,14,17,20-23,27,28)$. Sedang sebanyak 20 soal, yaitu nomor $(1-4,7,12$, $13,15,16,18,19,24-26,29-34)$, dan sukar sebanyak 1 soal, yaitu nomor 10 .

Hasil yang diperoleh dari perhitungan daya pembeda soal oleh peneliti mula-mula dikelompokkan menjadi 2 kelompok, yaitu kelompok atas dan kelompok bawah. Kelompok atas berjumlah 4 siswa dengan nilai lebih unggul dibanding kelompok bawah, yaitu nomor absen 9 dengan nilai 86.11, absen 18 dengan nilai 79.16, absen 9 dengan nilai 72.22, dan absen 2 dengan nilai 65.27. Nilai yang diperoleh kelompok bawah dengan jumlah 3 siswa yaitu, nomor absen 11 dengan nilai 48.61, absen 26 dengan nilai 34.72, dan absen 21 dengan nilai 33.33. Dari pengelompokkan di atas maka dihitung nilai daya pembeda soal dengan kategori sangat baik 15 . Kategori baik terdapat 12, serta kategori kurang baik terdapat 7. Soal yang memiliki daya beda baik dan cukup serta taraf kesukaran cukup maka tidak direvisi. Sedangkan soal valid tetapi dengan daya beda buruk dan memiliki taraf kesukaran kriteria mudah maka perlu direvisi, karena kemungkinan soal dapat ditebak dengan mudah jawabannya. Sedangkan soal dengan daya beda jelek dan memiliki taraf kesukaran kriteria sukar maka artinya siswa tidak ada yang menjawab, tidak 
dapat digunakan untuk mengukur kemampuan siswa.

Kurangnya waktu yang tersedia juga menjadi kendala, siswa menjadi tidak fokus kepada peneliti. Pada saat tes juga terjadi beberapa kecurangan siswa, sehingga hal itu sedikit mengganggu penelitian. Dari kelas kecil diperoleh data respon siswa dan hasil tes siswa. Tes yang dikerjakan siswa berupa essay singkat. Yang nantinya jawaban-jawaban siswa direduksi menjadi alternatif jawaban sehingga diperoleh draf II. Terdapat 4 alternatif pilihan, 1 alternatif jawaban benar (Option) dan 3 pengecoh (Distractor).

Subyek yang dijadikan uji kelas kecil berikutnya adalah 9 siswa kelas VIII B 25 SMPN 14 Madiun. Data yang diambil dalam uji coba kelas kecil ini adalah data berupa respon siswa terhadap produk pengembangan dan nilai siswa yang diambil dari tes. Pada siswa uji kelas kecil diberikan soal sebanyak 25 butir berupa pilihan ganda (Multiple Choice). Hasil yang didapatkan setelah melalui hasil analisis validitas, reliabilitas, daya beda dan taraf kesukaran. Diperoleh 15 soal valid. Dengan nilai reliabilitasnya sebesar 0,898 dapat dikatakan reliabel dengan kategori "sangat baik". Hasil yang diperoleh dari perhitungan daya pembeda
25 soal, terdapat soal oleh peneliti mulamula dikelompokkan menjadi 2 kelompok, yaitu kelompok atas dan kelompok bawah. Kelompok atas berjumlah 5 siswa dengan nilai lebih unggul dibanding kelompok bawah, yaitu nomor absen 9 dengan nilai 80, absen 11 dengan nilai 80, absen 14 dengan nilai 80, absen 26 dengan nilai 72 dan absen 19 dengan nilai 68. Nilai yang diperoleh kelompok bawah dengan jumlah 4 siswa yaitu, nomor absen 2 dengan nilai 48 , absen 21 dengan nilai 36, absen 6 dengan nilai 16, dan absen 18 dengan nilai 16. Dari pengelompokkan di atas maka dihitung nilai daya pembeda soal dengan kriteria baik sekali sejumlah 12 soal. Soal kriteria baik sejumlah 3. Soal kriteria cukup sejumlah 5 soal. Soal kriteria jelek sejumlah 5 soal. Pada uji kelas kecil yang telah dilakukan mendapatkan hasil data, 1 soal dengan kategori mudah, yaitu nomor 1, 22 soal dengan kategori sedang, yaitu nomor (1, 4-10, 12-25), 2 soal dengan kategori sukar, yaitu nomor 3 dan 11 . Secara keseluruhan soal dengan kategori sukar perlu untuk direvisi.

\section{SIMPULAN}

Hasil penelitian pengembangan instrumen tes diagnosis untuk mengukur tingkat kemudahan/kesukaran soal tersebut, mampu membedakan siswa yang 
sudah menguasai materi atau belum setelah diujikan di kelas VIII SMP/Mts menggunakan adaptasi model pengembangan prosedural menurut Sugiyono dan model pengembangan 4-D menurut Tiagarajan, Semmel dan Semmel diperoleh simpulan sebagai berikut:

Langkah-langkah pembuatan instrumen tes dalam penelitian ini yaitu, tahap eksplorasi meliputi analisis ujung depan, analisis siswa, menentukan materi, spesifikasi tujuan, menyusun instrumen tes, dan desain awal instrumen tes, sedangkan tahap pengembangan meliputi validasi ahli, uji kelas kecil dan uji coba terbatas.

Hasil penilaian yang dilakukan oleh validator terhadap produk pengembangan didapatkan hasil yaitu presentase ahli materi sebesar $95.33 \%$, dengan kualitas dari ketepatan, kebahasaan, dapat memberikan dampak bagi siswa dan dapat memberikan dampak bagi guru mendapat kriteria "sangat layak". Alat evaluasi ini mendapatkan kriteria penilaian yang baik, disetiap hasil rata-rata pada masingmasing nomor soal. Soal dengan skor 2.8 adalah nomor 8 dan 9, skor 3 adalah nomor 5 dan 7 , skor 3.2 adalah nomor 1 , $2,10,12$, dan 13 , skor 3.4 adalah nomor 3 , 4,11 , dan 14 , serta skor 3,8 adalah nomor 6. Saran dan komentar dari para ahli validasi soal pilihan ganda menyatakan bahwa kalimat sudah simpel, dan operasional, sudah bagus, indikator dan materi soal sudah sesuai.

\section{DAFTAR RUJUKAN}

Agustiana, I.. G. A. T. (2013). Konsep Dasar IPA Aspek Fisika dan Kimia.

Yogyakarta. Penerbit Ombak.

Anderson, et el. (2010). Pembelajaran, Pembelajaran dan Asesmen. Yogyakarta: Pustaka Belajar.

Arikunto, S. (2010). Prosedur Penelitian. Jakarta: Rineka Cipta.

Arikunto, S. (2012). Dasar-Dasar Evaluasi Pendidikan. Jakarta: Bumi Aksara.

Arikunto, S. (2013). Prosedur Penelitian. Jakarta: Rineka Cipta.

Firmansyah, A. (2014). Penerapan Pembelajaran Kooperatif Tipe STAD Untuk Meningkatkan Hasil Belajar Mata Pelajaran Memperbaiki Sistem Rem Pada Siswa Kelas XI TKR 3 di SMKN 3 Surabaya. JPTM (Online), Vol. (3:2).

Prihatni, Y. (2016). Pengembangan Instrumen Diagnostik Pada Mata Pelajaran IPA di SMP. JPTM (Online), Vl (20:1).

Purwanto. (2011). Evaluasi Hasil Belajar. Surakarta: Pustaka Pelajar.

Putra, N. (2012). Research \& Development. Jakarta: RajaGrafindo Persada. 
Riduwan, (2014). Dasar-Dasar Statistika.

Bandung: Alfabeta.

Salma, V. M. (2016). Pengembangan EDiagnostic Test Untuk Mengidentifikasi Pemahaman Konsep Fisika Siswa SMA Pada Pokok Bahasan Fluida Statis. JPTM (Online), Vol (5:1).

Sugiyono. (2012). Metode Penelitian Pendidikan. Bandung: Alfabeta.

Suwarto. (2012). Pengembangan Tes Diagnostik. Surakarta: Pustaka Pelajar.

Trianto. (2014). Model Pembelajaran Terpadu. Jakarta: Bumi Aksara..

Winasih, N. W. (2015). Pengembangan Multimedia Pembelajaran Interaktif Dengan Model 4D Mata Pelajaran IPA Kelas VIII Tahun Pelajaran 2014/2015 di SMP Negeri 3 Sawan. JTP (Online), Vol (3:1). 